\title{
Parietaria rechingeri Chrtek (Urticaceae); A New Record for Flora of Turkey
}

\author{
Türkiye Florası için Yeni Bir Tür Kaydı; Parietaria rechingeri \\ Chrtek (Urticaceae)
}

Research Article

Mehmet Firat*

Department of Biology, Faculty of Education, Yüzüncü Yıl University, Van, Turkey.

\section{A B S TR AC T}

arietaria rechingeri (Urticaceae) is described as a new record to the Flora of Turkey (C9, Şırnak). Detailed morphological description, photographs and distribution map of this new record has been given in this article.

\section{Key Words}

New record, Parietaria rechingeri, Urticaceae, Şırnak.

\section{öz}

arietaria rechingeri (Urticaceae) türü Türkiye Florası için ilk kez (C9, Şırnak) kaydedilmiştir. Bu makalede kaydın ayrıntılı morfolojik betimi, fotoğrafları ve yayılış haritası verilmiştir.

\section{Anahtar Kelimeler}

Yeni kayıt, Parietaria rechingeri, Urticaceae, Şırnak.

Article History: Received: Mar 24, 2017; Revised: Apr 8, 2017; Accepted: Jun 9, 2017; Available Online: Feb 20, 2018.

DOI: $10.15671 / \mathrm{HJBC} .2018 .212$

Correspondence to: M. Fırat, Department of Biology, Faculty of Education, Yüzüncü Yıl University, Van, Turkey. 


\section{INTRODUCTION}

Urticaceae Jussieu, the nettle plant, is a family of flowering plants consisting of herbs, shrubs and trees. The family, which consists 54 genera with more than 2000 speciesis, one of the larger genera in the Urticales and Eudicot Rosids [13]. Family members distributed throughout the tropics, subtropics and warm temperate regions. Urticaceae family also have economically important genera. Some of these genera are used to make cloth, fishing nets, ropes and some industrial materials [4-6]. Also because of allergenic source, some genus members are well studied.

There has been a debate on classification of Urticaceae. Gaudichaud [7] proposed a classification for members of Urticaceae, Cecropiaceae, Moraceae and Cannabinaceae. He classified all these families members as a single family. Later, Weddell [8-10] proposed to separate Moraceae and Cannabaceae from Urticaceae. According to the fruit characters, Kravtsova [11] divided Urticaceae into the three subfamilies: Urticoideae, Lecanthoideae, and Boehmerioideae. Recent phylogenetic studies showed that Urticaceae has three evolutionary lineages Boehmeriea-Cecropieae-ForsskaoleeaeParietarieae; Urticeae and Elatostemeae [12].
Parietaria L. is a genus consist of annual or perennial herbaceous. The genus is in BoehmerieaCecropieae-Forsskaoleeae-Parietarieae lineage. It is represented by 4 species in Turkey.

\section{MATERIALS and METHODS}

Parietaria rechingeri Chrtek, the material of this study, was collected in Cudi Mountains (Şırnak) (Figure 1), Şırnak in July 2013-2014. According to the description of Flora of Turkey and the East Aegean Islands [13], Flora of Turkey and the East Aegean Islands (Supplement) [14] it was concluded that collected materials were new record for Turkey flora. Detailed investigation of literatures $[15,16]$ showed that collected materials have been described as Parietaria rechingeri from Iraq. Collected materials were deposited at the Herbarium of Yüzüncü YıI University Science Faculty (VANF).

\section{Description}

Type: Iraq: Mosul, Jabal Khantur, nr. Sharanish, 1200 m, 4-9.07.1957, Rech.f. 12091 (Figure 2) Perennial herb, woody at the base with the old cortex whitish and cracking, 5-12 cm, caespitose with numerous ascending stems. Stems terete, striate, softly whitish-pilose. Leaves 4-16 mm, broadly ovate to elliptic, moderately softly

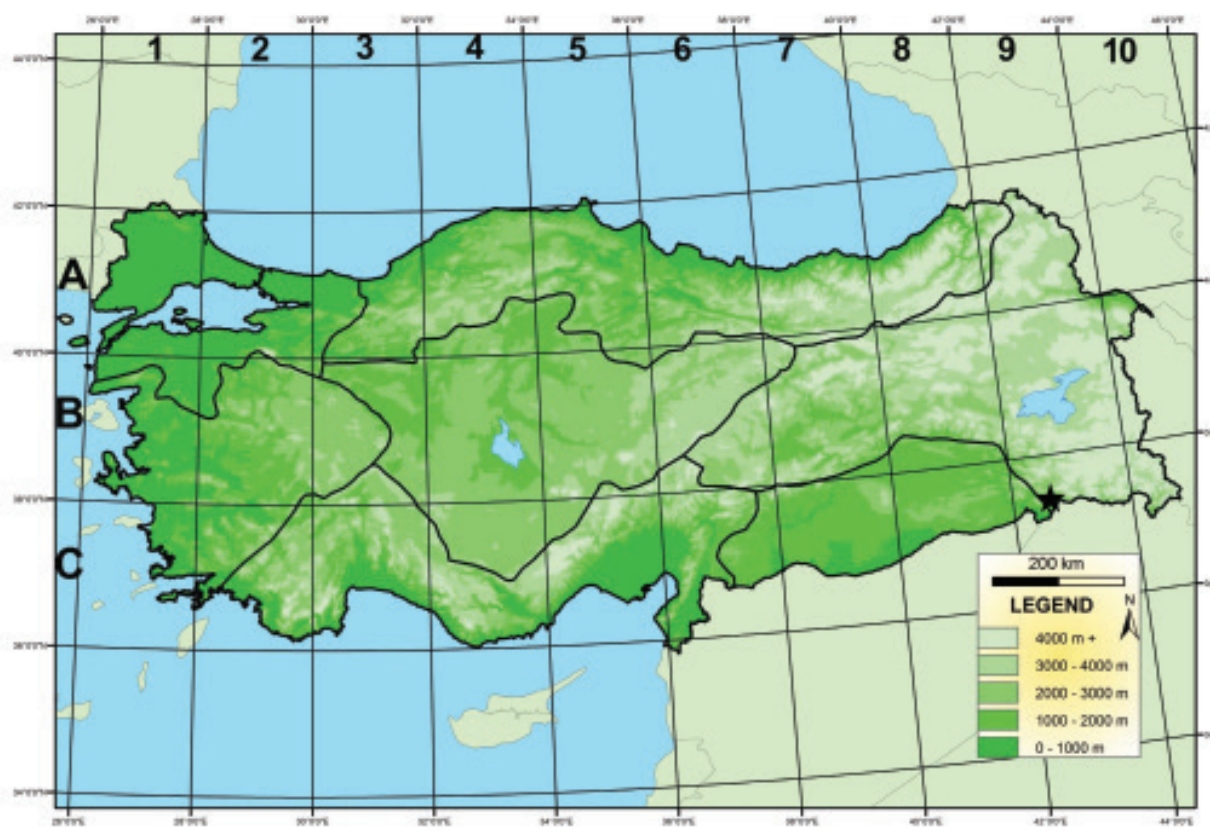

Figure 1. Geographical distribution of Parietaria rechingeri $(\star)$ in Turkey. 
pilose and pale on the lower surface, darker and subglabrous above, margins ciliate; primary veins 4 , the 2 lowest \pm opposite and sub-basal, the upper two alternate; leaf base truncate in some of the smaller leaves, mostly shortly cuneate, apex rather blunt to subacute; petioles slender, 2-3 mm, densely softly hairy. Inflorescence of two lateral clusters in the upper leaf-axils, each c. 5 $\mathrm{mm}$ long, flowers sessile. Bracts broadly ovate, 3-4 mm, \pm white-pilose, rather blunt to subacute, equalling and just concealing the flower-clusters, almost free. Male (hermaphrodite) flowers palestramineous, ellipsoid, the narrowly elliptical perianth segments c. $3 \mathrm{~mm}$, fused in the basal one-third with a slender midrib, darkly appressedpilose dorsally; ovary pale. Female flowers similarly ellipsoid, browner, the perianth segments almost free, with dark brown borders fusing with the thick midrib at the subacute apex; ovary pale, c. $2 \mathrm{~mm}$, ellipsoid. No mature achenes seen.
Examined material: Turkey. C9 Şırnak: Cudi Mountains, Bılgan region, rocky slopes, $969 \mathrm{~m}$, $37^{\circ} 25^{\prime} 11^{\prime \prime} \mathrm{N}, 42^{\circ} 38^{\prime} 57^{\prime \prime} \mathrm{E}, 15.07 .2014$ M. Firat 31054, VANF

Habitat: Rock crevices on mountain, on calcareous rock

Phenology: Flowering times July, Fruiting time October

Distribution in Turkey: Şırnak

General distribution: North part of Iraq

Associated with: Campanula radula Fisch. ex Tchich., Campanula mardinensis Bornm. \& Sint., Teucrium chasmophyticum Rech.f., Pimpinella sintenisii H.Wolff, Erygeron sp.

Vernacular name: In Şırnak province, indigenous people use the name "Padûsek" for Parietaria.

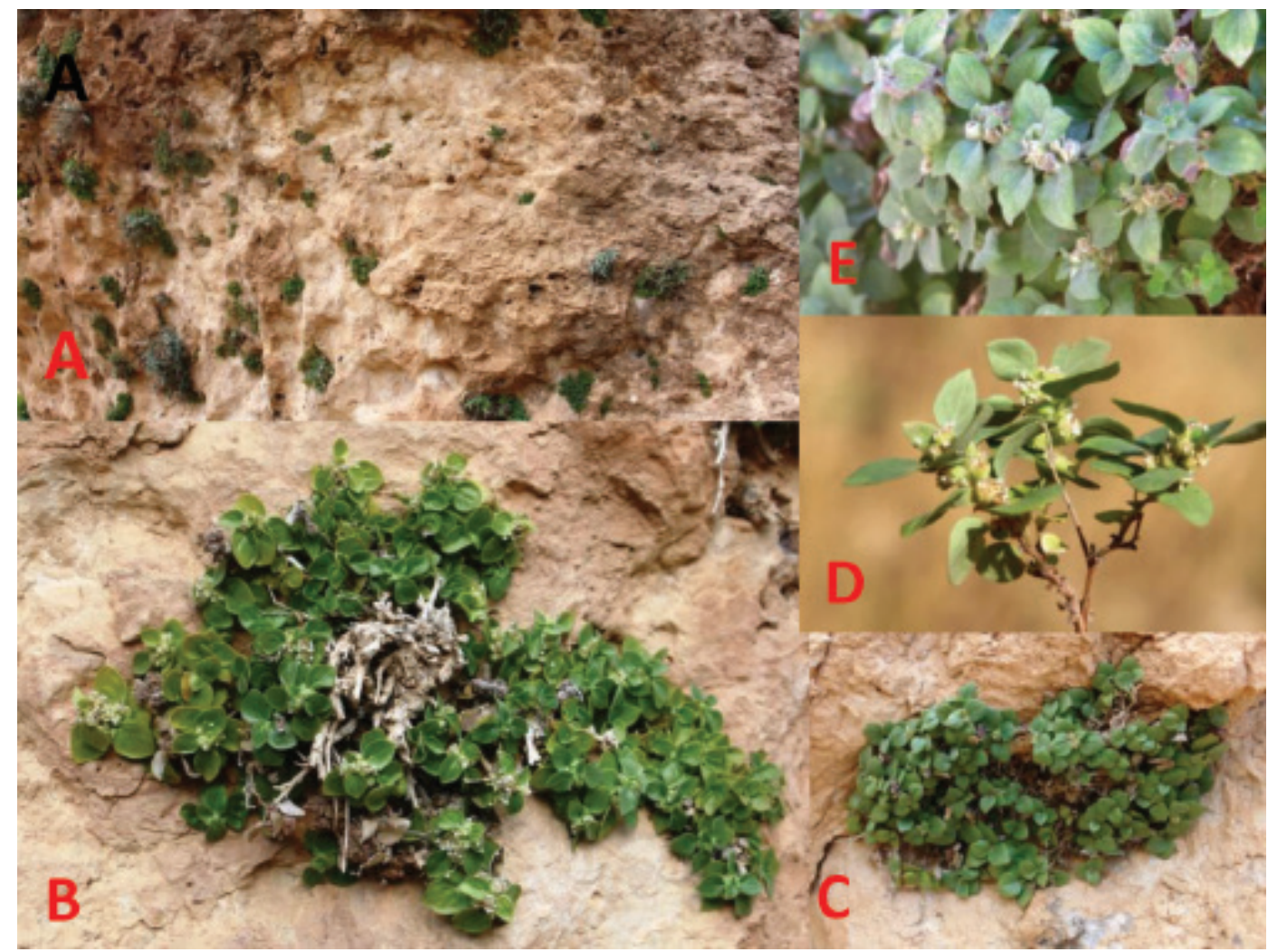

Figure 2. Parietaria rechingeri; A-B-C Habit and Habitat, D. Flower, E. Fruit. 


\section{Key to closely related Parietaria species in Turkey}

1. Bracts becoming indurate in fruit and \pm saccate at base, forming an involucre round the 3 -flowered inflorescence

5. P. cretica

1. Bracts not indurate or saccate at base in fruit

2. Annual; female flowers to $1.75 \mathrm{~mm}$

4. P. Iusitanica

2. Perennial; female flowers $2 \mathrm{~mm}$ or more

3. Flower clusters congested, concealed within the broad bracts

3. P. rechingeri

3. Flower clusters not concealed within the bracts

4. Perianth of hermaphrodite flowers accrescent, tubular in fruit; female flowers inconspicuous, not or scarcely exceeding bracts

.1. P. judaica

4. Perianth of hermaphrodite flowers scarcely accrescent, remaining campanulate in fruit; female flowers conspicuous, distinctly exceeding bracts

2. P. officinalis

\section{RESULTS and DISCUSSION}

In our country, the genus Parietaria is represented by 4 species. The number of taxa in our country has risen to 5 with this new record. Thus, this has contributed to both the region of Şırnak where limited information is known about its flora in private and the Flora of Turkey.

\section{References}

1. Friis, The Urticaceae: a systematic review. In: P.R. Crane, S. Blackmore, (Eds.), Evolution, Systematics, and Fossil History of the Hamamelidae. Clarendon Press, Oxford, (1989) 285-308.

2. A. Takhtajan, Flowering Plants. Springer, (2009) 281.

3. P.F. Stevens, (2001 onwards). Angiosperm Phylogeny Website. http://www.mobot.org/MOBOT/research/ APweb/. 2012.

4. S.C. Singh, R. Shrestha, Girardinia diversifolia (Urticaceae), a nonconventional fiber resource in Nepal. Econ. Bot., (1988) 445-447.

5. L.G. Angelini, A. Lazzeri, G. Levita, D. Fontanelli, C. Bozzi, Ramie (Boehmeria nivea (L.) Gaud.) and Spanish Broom (Spartium junceum L.) fibres for composite materials: agronomical aspects, morphology and mechanical properties. Ind. Crops Prod. 11 (2000) 145-161.

6. E. Bodros, C. Baley, Study of the tensile properties of stinging nettle fibres (Urtica dioica). Mater. Lett. 62 (2008) 2143-2145.
7. C. Gaudichaud, Botanique, part 12. In: H.D. Freycinet (Ed.), Voyage autour du monde executé sur les corvettes de S.M. I' Uranie et la Physiciene'. Pilet-Aine, Paris, (1830) 465-522.

8. H.A. Weddell, Revue de la famille des Urticacées. Ann. Sci. Natl. Bot. Ser., 4 (1854) 173-212.

9. H.A. Weddell, Monographie de la famille des Urticées. Nouv. Archieves Mus. Hist. Nat., 9 (1856) 1-592.

10. H.A. Weddell, Urticacées. In: Candolle, A.D. (Ed.), Prodromus Systematis Naturalis Regni Vegetabilis. Victoris Masson et Filii, Paris, (1869) 32-235.

11. T.I. Kravtsova, In: N.N. Tzvelev, A.E. Vassilyev (Eds.), Comparative Carpology of the Urticaceae Juss. KMK Scientific Press, Moscow, (2009) 136-266.

12. J.T. Hadiah, B.J. Conn, C.J. Quinn, Infra-familial phylogeny of Urticaceae, using chloroplast sequence data. Australian Systematic Botany, 21 (2008) 375385.

13. C.C. Townsend, Parietaria L. In: P.H. Davis, (ed.), Flora of Turkey and the Aegean Islands Vol. 7:. Edinburgh Univ. Press, Edinburgh. (1982) 636-639.

14. A. Güner, N. Özhatay, T. Ekim, K.H.C. Başer, Flora of Turkey and the East Aegean Islands, vol. 11. Edinburgh University, Press, Edinburgh, (2000) 503.

15. C.C. Townsend, Parietaria L. In: C.C. Townsend, E. Guest (eds.), Flora of Iraq Vol: 4, Ministry of Agriculture \& Agrarian Reform, Baghdad. (1980) 100105.

16. T. Ekim, Parietaria L. In: A. Güner, S. Aslan, T. Ekim, M. Vural, M.T. Babaç, (eds). Türkiye Bitkileri Listesi (Damarlı Bitkiler), Nezahat Gökyiğit Botanik Bahçesi ve Flora Araştırmaları Derneği Yayını, İstanbul, (2012) 881-882. 